\title{
Corporate Board Attributes And Conditional Accounting Conservatism: Evidence From French Firms
}

\author{
Nabila Boussaid, University of Liège, Belgium \& University of Sousse, Tunisia \\ Taher Hamza, University of Carthage, Tunisia \\ Danielle Sougné, University of Liège, Belgium
}

\begin{abstract}
We investigate the relationship between corporate board of directors' attributes and conditional accounting conservatism in the French context. Using a pooled regression model over the period 2009-2012, our empirical results can be summarized as follows. First, greater board activity encourages more conservative reporting in financial statements. Second, larger board size diminishes conditional accounting conservatism. Lastly, there is a positive association between gender diversity and accounting conservatism. As a robustness test, we use alternative measures of accounting conservatism, namely time series and accrual-based measures in addition to asymmetric timeliness of earnings. Our findings suggest that boards of directors' attributes are an important factor in determining the financial reporting quality of French firms.
\end{abstract}

Keywords: Conditional Accounting Conservatism; Corporate Board Size; Gender Diversity; Board Activity

\section{INTRODUCTION}

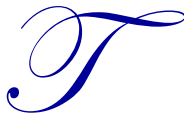

he recent spate of accounting scandals such as those surrounding Enron, WorldCom and Tyco have shaken investor confidence in financial reports. In an attempt to enhance the credibility of reporting, regulators, practitioners, and academics have worked to develop more sophisticated accounting practices. A growing body of research encourages the use of conservative reporting practices. Traditionally, accounting conservatism is defined by the adage "anticipate no profit, but anticipate all losses" (Bliss, 1924). This implies that losses will be identified much sooner, while the recognition of profit is postponed until gains are realized. Recently, alternative definitions have emerged. For example, in the pioneering study conducted by Basu (1997), accounting conservatism is defined as "the accountant's tendency to require a higher degree of verification to recognize good news as gains than to recognize bad news as losses". Ryan (2006) states that conditional accounting conservatism involves firms writing down the book value of net assets in a timely fashion upon receiving sufficiently bad news, but not writing up net assets as quickly upon receiving correspondingly good news. Such accounting leads to an asymmetric timeliness in recognition of good news vs. bad news. This asymmetric timeliness of recognition is also referred to as conditional accounting conservatism, ex-post conservatism, news dependent, income statement conservatism, or earnings conservatism (see e.g. Beaver and Ryan, 2005; Ball and Shivakumar, 2005). In accounting literature, there is a distinction between conditional and unconditional accounting conservatism. Unconditional accounting conservatism refers to the persistent understatement of shareholders' equity due to routinely biased accounting rules, independent of contemporaneous economic news (see e.g. Felthman and Ohlson, 1995; Garcia Lara and Mora, 2004; Beaver and Ryan, 2005; Ryan, 2006). This type of conservatism is known as ex-ante conservatism, news independent or balance sheet conservatism. In this study, we only focus on conditional accounting conservatism based on the evidence of Garcia Lara et al. (2009) that conditional accounting conservatism plays an important role in corporate governance. Prior studies have identified four main causes for the existence of accounting conservatism, and all of them concur in highlighting that conservatism is helpful to financial statement users. First, accounting conservatism emerges as a part of an efficient contracting mechanism. Many contracts between firms and their various parties make use of accounting conservatism in financial statements. 
Current accounting studies show that accounting conservatism benefits boards of directors, investors, less informed shareholders, and debt-holders, among other concerned parties. For instance, it allows boards of directors to detect negative net present value projects early on ${ }^{1}$ (Ball, 2001), and increase future investment opportunities (Garcia Lara et al., 2009). Since accounting conservatism limits managers' opportunistic behaviour (Watts, 2003; Kwon et al., 2001 and Chen et al., 2007), conservatism helps reduce earnings manipulation (Watts, 2003) and increase firm value (Watts and Zuo, 2012). Lafond and Watts (2008) argue that accounting conservatism reduces both information asymmetry and morally hazardous agency conflicts between managers and less informed shareholders. Second, shareholder litigation leads firms to report more conservatively. Understatement of net assets is less likely to incur litigation costs than overstatement of net assets (Watts, 2003). Third, taxation can encourage the use of conservative reporting. The use of conservative accounting methods and policies incurs lower taxes. Indeed, by requiring a higher degree of verification for recognizing good news than bad news in financial statements, a firm can pay a lower tax in its current fiscal year and increase its value (Watts, 2003). Lastly, regulation also provides incentives for conservatism. Standard-setting authorities may face political pressure and public criticism. These bodies favour conservative accounting practices as this reduces the likelihood of engendering political costs (Watts, 2003).

Existing research suggests that good corporate governance improves accounting quality (Cohen et al., 2004). Basu (1997), Watts (2003) and Ahmed and Duellman (2007) support the assertion that accounting conservatism is one of the most important attributes of higher accounting quality. However, the relation between corporate governance and accounting conservatism has not been extensively investigated. For example, Garcia Lara et al. (2009) documented that the incorporation of bad news into earnings is significantly timelier in well-governed firms. They point out that accounting conservatism provides early notice of bad news to governance bodies by easing early investigation in their reasons. Lim (2011) and Ahmed and Henry (2012) document that voluntary corporate governance has a positive influence on conditional accounting conservatism. Meanwhile, Chi et al. (2009) find that accounting conservatism is used as a substitute for other governance mechanisms in alleviating agency problems. The authors argue that firms may rely on accounting conservatism to make up for weaknesses in corporate governance.

Recent advances in economic theory show that the board of directors is an important component in corporate governance. The board of directors has the power to hire and fire senior management and to monitor their activities effectively (see e.g. Fama and Jensen, 1983; Williamson, 1983; Beasley, 1996; Forbes and Milliken, 1999; Adams, 2000). The board of directors serves to mitigate agency problems arising from asymmetric information between managers and shareholders (Jensen and Meckling, 1976). Boards of directors require verifiable information to monitor manager activity and are therefore expected to insist on higher reporting quality (Ahmed and Duellman, 2007). Given their important role in accounting behaviour, boards of directors have been the focus of a large body of research over the years. However, the link between boards of directors and accounting conservatism has not been extensively investigated. Prior studies focused mainly on three board attributes, namely: board size; board independence; and board leadership (Beekes et al., 2004; Ahmed and Duellman, 2007; Chi et al., 2009; Lim, 2011 and Ahmed and Henry, 2012). In this work, we include the additional board attributes of gender diversity and board activity.

Our study differs from those of Beekes et al. (2004), Ahmed and Duellman (2007), Garcia Lara et al. (2007, 2009), Lim (2011), and Ahmed and Henry (2012) in several ways. First, in recent years, a spate of legislative reforms have been designed to increase female representation on boards ${ }^{2}$. Accordingly, our research considers the effect of female directorship on accounting conservatism. Second, since the effect of board activity on accounting conservatism remains an unanswered question, we include in our study proxies for board meeting frequency and board attendance. Third, we extend the existing literature on board attributes and accounting conservatism by exploring this relation in the French context, which constitutes a uniquely European environment that differs markedly from the English-speaking countries in terms of corporate governance and accounting practices. To test our hypotheses, we use the SBF120 French firms over the period 2009-2012. Our main findings can be summarized as follows. First, both board activities are positively associated with accounting conservatism. Board meeting

\footnotetext{
${ }^{1}$ If managers know that losses generated by negative NPV projects will be reflected in financial statements during their tenure in a more timely manner, they are less likely to invest in NPV projects because of factors such as reputation, career prospects and earnings-linked compensation.

${ }^{2}$ In France, a bill was passed in January 2011 requiring $20 \%$ of directors of listed company boards to be women by 2014 , rising to $40 \%$ by 2017 (Most recent Spencer Stuart Board indexes).
} 
frequency and attendance improve board governance, which in turn are likely to improve the financial reporting quality in the French context. Second, a greater board size has a negative effect on conditional accounting conservatism. Large boards are associated with less effective monitoring, confused decision-making and reduced membership coordination (Eisenberg et al., 1998), which can reduce the quality of accounting scrutiny. In addition, we find a positive association between gender diversity and conditional accounting conservatism. This positive influence suggests that female directorship improves board monitoring, which in turn is likely to require a higher degree of verification for recognizing good news than bad news in financial statements. Lastly, board leadership and independence do not appear to be significantly related to conditional accounting conservatism.

The remainder of the paper is structured as follows. Section 2 reviews the existing literature on board attributes and accounting conservatism and develops the research hypotheses. The sample selection and methodology used to test the hypotheses are presented in section 3. Section 4 reports the results of the empirical tests and provides a robustness check while section 5 concludes our findings.

\section{LITERATURE REVIEW AND HYPOTHESES DEVELOPMENT}

This section discusses the existing literature concerning the effect of boards of directors' attributes on accounting conservatism. We consider three board of directors dimensions: board composition; gender diversity; and board activities. We will focus on three sub-components of board composition: board size; board independence; board leadership; and two sub-components of board activities, which are board meeting frequency and board attendance.

\subsection{Board Composition And Accounting Conservatism}

\subsubsection{Board Size And Accounting Conservatism}

The existing literature on corporate governance tends to agree that smaller boards can be more efficient than larger ones. Boards that become too large, it is claimed, are hampered by coordination and communication costs and prone to free-riding among board members (Jensen, 1993). Consistent with this assertion, Yermack (1996), Eisenberg et al. (1998) and Hermalin and Weisbach (2003) find support for a negative association between board size and performance. Beasley (1996) documents that the likelihood of financial statement fraud is positively related to board size. These results confirm that large boards suffer from lack of monitoring (Ahmed and Duellman, 2007). In contrast, Klein (2002) and Lipton and Lorsch (1992) argue that larger boards offer greater monitoring and control capabilities than small boards due to their ability to distribute board control tasks over a greater number of directors. Consistent with this argument, Xie et al. (2003) find a negative association between board size and earnings management. They conclude that larger boards are more effective monitors than small boards, because they are able to pool directors' experience and expertise. The relationship between board size and accounting conservatism has been the subject of limited research and is not well understood. Bushman et al. (2004), Ahmed and Duellman (2007) and Lim (2011) conclude that board size is unrelated to the asymmetric timeliness of earnings, whereas Ahmed and Henry (2012) find that small boards are associated with asymmetric timeliness of good cash flow and share return news. Their findings are similar to those of Vafeas (1999) who argues that in a small board, directors have more opportunities to discuss accounting in detail. Given these conflicting views, we offer two possible relationships between board size and conditional accounting conservatism. The hypotheses are stated as follows:

H1.a: There is a negative relation between board size and conditional accounting conservatism

H1.b: There is a positive relation between board size and conditional accounting conservatism

\subsubsection{Board Independence And Accounting Conservatism}

Being independent of management influence, outside directors are essential to the management of a firm (Weisbach, 1988). Fama and Jensen (1983) argue that outside directors are expected to offer shareholders the greatest protection against managerial opportunism. Previous studies show that outside and inside directors may 
have different incentives regarding accounting practices, in particular regarding accounting conservatism. Board of directors may use conservative accounting to reduce agency costs (Watts, 2003; Ahmed and Duellman, 2007). Outside directors will improve corporate governance control and the effectiveness of the board of directors (Fama and Jensen, 1983). Therefore, we expect them to encourage more conservative attitude in financial reporting (Beekes et al., 2004; Bushman et al., 2004; Ahmed and Duellman, 2007). By contrast, inside directors may harm shareholders by making the board less effective. In such situation, management may compromise the quality of financial reporting by requiring less conservative practices. The empirical evidences of Beekes et al. (2004) support this contention in UK boards and show that firms with a relatively high proportion of outsiders tend to be more conservative. Thus, a board with a relatively high proportion of outsiders is more likely to effectively monitor the management team and force them to recognize bad news in a timelier fashion than good news in financial reporting. Previous studies on board composition such as that of Ahmed and Duellman (2007) argue that boards dominated by insiders have a lower asymmetric timeliness coefficient than boards with lower levels of insiders. Hence, they suggest that boards dominated by insiders are likely to provide managers with more incentives to choose aggressive (less conservative) accounting methods. Meanwhile, Bushman et al., (2004) and Ahmed and Henry (2012) find no relation between board independence and earnings timeliness. Other studies show that the presence of outside directors reduces the occurrences of financial statement fraud (Beasley, 1996; Dechow et al. 1996) and earnings management (Klein, 2002; Davidson et al., 2005). Beekes et al. (2004), among others, maintain that as the number of independent directors increases on a board, the firm's monitoring capability increases and it is therefore expected to insist on greater accounting conservatism. The preceding discussion leads to our next hypothesis:

H2. There is a positive association between board independence and conditional accounting conservatism

\subsubsection{Board Leadership And Accounting Conservatism}

The chairperson oversees the work of the board and its meetings, and the process of hiring, firing, evaluating, and compensating the CEO (Jensen, 1993). The separation of CEO and chairperson positions is important for the effective functioning of the board. As a result, CEO duality may reduce the monitoring abilities of the board and provide greater opportunities for managerial entrenchment (Dechow et al. 1995; Klein, 2002; Rahman and Haniffa, 2005). Few studies examine the association between CEO duality and accounting conservatism. Furthermore, the empirical evidences to date are inconclusive. Ahmed and Duellman (2007) find that CEO duality is unrelated to the asymmetric timeliness when earnings and returns are cumulated. Krishnan and Vivanathan (2008) and Lim (2011) find that the separation of the CEO's and chairperson's roles, as an indicator of good governance, is positively associated with accounting conservatism. With regard to the existing research, the following hypothesis is proposed:

H3. There is a negative relation between board leadership and conditional accounting conservatism

\subsection{Gender Diversity And Accounting Conservatism}

The existing literature reveals that female representation on boards of directors is an important factor required by investors (Campbell and Minguez-Vera, 2008; Adams and Ferria, 2009). The need to build board diversity stems from the following motivations. First, female directors are significantly more risk-averse and less prone to overconfidence than male directors in decision-making (see e.g. Riley and Chow, 1992; Ambrose and Schminke, 1999 and Krishnan and Parsons, 2008). Second, female directors exhibit independent thinking (see e.g. Carter et al., 2003 and Hillman et al., 2007), which implies that they make decisions in different ways to male directors. Third, Jelinek and Adler (1988) and Cohen et al. (1998) document that female directors develop and practice a 'trust-building' leadership style more than a 'command' style favoured by their male counterparts. 'Trustbuilding' presupposes more information disclosure and lower information asymmetry (Srinidhi et al., 2011). Lastly, female directors are less tolerant than male directors towards opportunistic behaviour (Srinidhi et al., 2011). Therefore, gender diversity is likely to increase board's effectiveness and monitoring capacity (Adams and Ferreia, 2009). Recent empirical studies explore whether female directorship affects a firm's outcomes. Carter et al. (2003) and Campbell and Minguez-Vera (2008) find a positive relation between female directorship and firm performance. Srinidhi et al. (2011) find that firms with female board members exhibit a higher earnings quality. They point out the tangible consequence of the monitoring exerted by female directors. By contrast, Shrader et al. (1997) report no 
significant association between gender diversity on boards and firm performance. Based on several empirical findings, we propose that firms with female directorship will improve board monitoring, which in turn is likely to require a higher degree of verification for recognizing good news than bad news in financial statements. Therefore, the following hypothesis is proposed:

H4. There is a positive association between gender diversity and conditional accounting conservatism

\subsection{Board Activities And Accounting Conservatism}

Current research on board effectiveness identifies the level of board meeting activity as a primary measure of directorial influence (see e.g. Vafeas, 1999). Conger et al. (1998) note that the board meeting is an important opportunity to discuss and exchange ideas and monitor the management team. Prior studies find that more active boards lead to favourable outcomes. Jensen (1993), Conger et al. (1998) and Garcia Lara el al. (2007) document that the frequency of board meetings is an important attribute contributing to good corporate governance. Zhang et al. (2007) find a positive relation between board meeting frequency and internal control weaknesses. Vafeas (1999) documents that boards with high meeting frequency improve financial performance. Xie et al. (2003) document a negative association between board meeting frequency and earnings management, indicating that when boards meet more often they are able to limit discretionary accruals. Adams and Ferreira (2009), among others, argue that board attendance is an indication of directors' diligence because it is the primary channel through which they have access to specific information about managerial activities. If directors attend board meetings regularly, the accounts reporting process benefits from greater oversight. Thus, based on the previous findings, we can summarize that board meeting frequency and attendance allow directors to assign more time to discuss the financial reporting process. Overall, empirical evidences show that these two board activities induce managers to produce more conservative accounting practices by presenting bad news in a more timely manner than good news. Accordingly, we test these two hypotheses:

H5.a: There is a positive relation between board meeting frequency and conditional accounting conservatism

H5.b: There is a positive relation between board attendance and conditional accounting conservatism.

\section{RESEARCH DESIGN}

To examine the relation between board attributes and conditional accounting conservatism, we use the SBF120 French firms over the period 2009-2012 period. To estimate conditional accounting conservatism, we use the Basu model:

$$
\frac{E_{i, t}}{P_{i, t-1}}=\beta_{0}+\beta_{1} R_{i, t}+\beta_{2} D_{i, t}+\beta_{3} D_{i, t} * R_{i, t}+\varepsilon_{i, t}
$$

Where:

$\beta_{0}$ is the intercept;

$E_{i, t} / P_{i, t-1}$ represents annual earnings before extraordinary items per share divided by the share price at the beginning of the period for the firm i;

$R_{\mathrm{i}, \mathrm{t}}$ is the buy-and-hold return for the firm $\mathrm{i}$, beginning the $4^{\text {th }}$ month of fiscal year $\mathrm{t}$ and ending 4 months after the end of the fiscal year;

$D_{\mathrm{i}, \mathrm{t}}$ is an indicator dummy variable for the firm $\mathrm{i}$, equal to 1 in the case of bad news (negative or zero return) and 0 in the case of good news (positive return); and

$\varepsilon$ is an error term.

Historical stock prices were obtained from the Datastream database and financial data are drawn from the Worldscope database. We hand-collected all board attributes from the companies' annual reports.

In the above regression, $\beta_{1}$ measures the response of earnings to returns when returns are positive and $\left(\beta_{1+} \beta_{3}\right)$ measures the response when returns are negative (Basu, 1997). Conservatism implies $\left(\beta_{1+} \beta_{3}\right)>\beta_{1}$, that is when 
$\beta_{3}>0$. The coefficient on the interaction term $\beta_{3}$ is the measure of conservatism and is referred to as the asymmetric timeliness coefficient (Basu, 1997). $\beta_{3}$ is expected to be significantly positive, implying that more conservative firms have greater asymmetric verifiability between gains and losses (Basu, 1997; Beekes et al., 2004; Garcia Lara et al., 2007). ${ }^{3}$ However, despite the widespread use of this model in literature on accounting, Roychowdhury and Watts (2007) highlight that this model can introduce substantial measurement error because it incorporates only a single year of data (in returns and earnings). The authors therefore suggest incorporating returns and earnings cumulatively over longer periods. In this paper, we adopted the corrective approach suggested by Roychowdhry and Watts (2007) and cumulated earnings and returns over several years when estimating conditional accounting conservatism.

Table 1 summarizes the criteria used to screen our sample. We eliminate the financial and banking firms (SIC codes between 6000 and 6999) from our sample, given that they have different accounting, financial and operating. In addition, 34 firm-year observations were excluded due to missing data. As Table 1 indicates, the above process leaves 374 firm-year observations from the original sample. Table 1 (panel B) describes the industry membership of our sample assigned on the basis of 4-digit SIC:

Table 1. Sample Collecting Procedures And Distribution Of Companies In Sample By Industry

\begin{tabular}{|c|c|c|c|c|c|}
\hline \multicolumn{6}{|c|}{ Panel A: Sample collection procedure } \\
\hline & & \multicolumn{4}{|c|}{ Firm-year observations } \\
\hline \multicolumn{2}{|l|}{ Initial sample } & \multicolumn{4}{|c|}{480} \\
\hline \multicolumn{2}{|c|}{ (-) Financial and insurance firms } & \multicolumn{4}{|c|}{72} \\
\hline \multicolumn{2}{|c|}{ (-) Missing data/Not continuously listed } & \multicolumn{4}{|c|}{34} \\
\hline \multicolumn{2}{|l|}{ Total } & \multicolumn{4}{|c|}{374} \\
\hline \multicolumn{6}{|c|}{ Panel B: Sample distribution of industry } \\
\hline Industry & Sic Codes & 2009 & 2010 & 2011 & 2012 \\
\hline Petroleum & 13,29 & 3 & 3 & 3 & 3 \\
\hline Consumer durable & $25,30,36,37,50,55,57$ & 18 & 19 & 19 & 19 \\
\hline Basic Industry & $10,12,14,24,26,28,33$ & 10 & 10 & 11 & 12 \\
\hline Food\&Tobacco & $1,2,9,20,21,54$ & 8 & 7 & 7 & 7 \\
\hline Construction & $15,16,17,32,52$ & 4 & 4 & 4 & 4 \\
\hline Capital Goods & $34,35,38$ & 8 & 8 & 8 & 8 \\
\hline Transportation & $40,41,42,44,45,47$ & 2 & 2 & 2 & 2 \\
\hline Utilities & $46,48,49$ & 6 & 7 & 7 & 7 \\
\hline Textile and Trade & $22,23,31,51,53,56,59$ & 1 & 1 & 1 & 3 \\
\hline Services & $72,73,75,76,80,82,87,89$ & 21 & 21 & 22 & 22 \\
\hline Leisure & $27,58,70,78,79$ & 5 & 5 & 5 & 5 \\
\hline Other & & 5 & 5 & 5 & 5 \\
\hline
\end{tabular}

\subsection{Proxies For Explanatory Variables And Control Variables}

Our study tries to explain the relation between boards of directors' attributes and conditional accounting conservatism. In this section, we provide the definitions for the explanatory variables (see Table 2). Furthermore, to reduce the potential effect of the omitted variables, we also include in our model three control variables: (1) firm size; (2) litigation; and (3) Xlist.

Firm size is represented by the natural logarithm of total sales. The firm size was log-transformed to correct skewness. Watts and Zimmerman (1978) assert that larger firms are likely to attract greater public scrutiny than smaller firms, and face greater political costs in the event of irresponsible accounting. Therefore, we expect that larger companies would be more cautious in recognizing gains and faster in recognizing losses in order to avoid litigation.

Litigation is represented by an indicator variable coded 1 if the company is classified as a high-ligation risk industry, and 0 otherwise. High-litigation industries are firms with SIC codes of 2833-2836, 3570-3577, 3600-3674,

${ }^{3}$ The notion behind Basu's measure of conservatism is that bad news is incorporated into earnings faster than good news (asymmetric verifiability). 
5200-5961, and 7370. The cost of litigation is higher in companies that overstate earnings and net assets than companies that understate net assets and earnings (Watts, 2003). The market will punish overstatement more than understatement of net assets and earnings by the reducing market value of the company. This decrease in market value may reduce shareholder wealth. To avoid financial shareholder harm, good management provides incentives to record bad news earlier than good news in financial reporting (Qiang, 2007).

XLIST (crosslisting) is a dummy variable equal to 1 if the firm has an ADR traded in the U.S. that requires reconciliation to U.S GAAP and 0 otherwise. Recent cross-listing literature suggests that firms that cross-list in one or more foreign exchanges in addition to their domestic exchanges have incentives to produce more informative accounting reports (Lang et al., 2006).

Table 2. Independent Variables Definition

\begin{tabular}{lll}
\hline \multicolumn{1}{c}{ Variables } & Name & \multicolumn{1}{c}{ Measure } \\
\hline Explanatory Variables & BS & The natural logarithm of the total number of directors serving on the board. \\
\hline Board Size & BI & $\begin{array}{l}\text { The number of independent directors divided by board size (proportion of } \\
\text { independent directors) }\end{array}$ \\
\hline Board Leadership & DUAL & $\begin{array}{l}\text { A dummy variable, equal to 1 if the same person serves as both CEO and } \\
\text { chairperson of the board, and 0 otherwise. }\end{array}$ \\
\hline Board Meeting & MEET & The natural logarithm of board meeting held per year. \\
\hline Board Attendance & ASSID & The percentage of board assiduity. \\
\hline Gender Diversity & GEND & The percentage of female directors on the board. \\
\hline Firm Size & SIZE & $\begin{array}{l}\text { The natural logarithm of total sales. The firm size was log-transformed } \\
\text { to correct skewness. }\end{array}$ \\
\hline Litigation & LIT & $\begin{array}{l}\text { A dummy variable, equal to 1 if the company is classified as a high-ligation } \\
\text { risk industry, and 0 otherwise. High-litigation industries are firms with SIC } \\
\text { codes of 2833-2836, 3570-3577, 3600-3674,5200-5961, and 7370. }\end{array}$ \\
\hline Xlist & LIST & $\begin{array}{l}\text { A dummy variable, equal to 1 if the firm has an ADR traded in the U.S. that } \\
\text { requires reconciliation to U.S. GAAP, and 0 otherwise. }\end{array}$ \\
\hline
\end{tabular}

\subsection{Model Specification}

To investigate the association between accounting conservatism and board attributes, the standard Basu's model was modified by introducing the variable of board attributes. Each independent and control variable included in the model interacts with $R, D$, and $R^{*} D$.

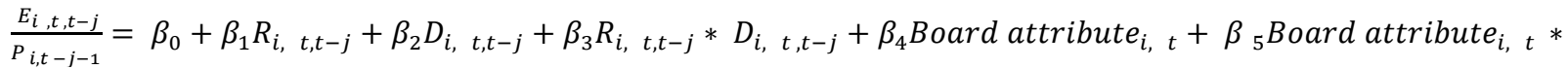

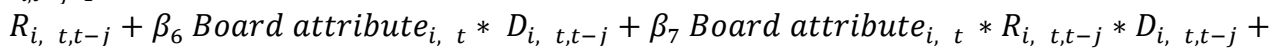

Other board attributes ${ }_{i, t}$ \& Control variables ${ }_{i, t}+Y r+\epsilon_{t}$

Where:

$\beta o$ is the intercept;

$E_{i, \mathrm{t}, \mathrm{t}-\mathrm{j}}$ is earnings before extraordinary items and discontinued operation per share for the firm i cumulative from year $\mathrm{t}-\mathrm{j}$ to year $\mathrm{t}$, with $\mathrm{j}$ varying from 0 to 3 ;

$P_{i, t, t-j-1}$ is the share price at the end of the year $\mathrm{t}$ for the firm $\mathrm{i}$;

$R_{i, \mathrm{t} t \mathrm{t}-\mathrm{j}}$ is the buy-and-hold return for the firm starting 4 months after the end of the fiscal year $\mathrm{t}-\mathrm{j}-1$ and ending 4 months after the end of the year t;

$D_{i, \mathrm{t} t \mathrm{t- \textrm {j }}}$ is an indicator variable set to 1 if $R_{i, \mathrm{t} t \mathrm{-j}}$ is negative and 0 otherwise; and

$\epsilon_{t}$ is an error term in year t.

We included three dummy variables in our regressions (Yr) that control for fixed year effects. The coefficient of the interaction term $R_{i, t, t-j} * D_{i, t, t-j}$ with the explanatory and control variables represents the effect of the respective 
variable on asymmetric timeliness. For example, the effect of board attribute on asymmetric timeliness is observed on $\beta_{7}$, which is the coefficient of the interaction term $R_{i, t, t-j} * D_{i, t, t-j}$ with board attribute. The interaction terms between independent variables and the components of accounting conservatism measure $\left(R_{i, t, t-j}, D_{i, t, t-j}\right.$ and $R_{i, t, t-j} * D_{i, t, t-j}$ ) in the Basu (1997) model raises the concern of potential multi-collinearity problems. To mitigate this problem, we mean-center all the continuous variables and then interact them (Cronbach, 1987 and Aiken and West, 1991). The Granger causality test was employed to discern whether the direction of causality flows from earnings to returns or vice versa. We find evidence of significant unidirectional relation from earnings to returns.

\section{EMPIRICAL ANALYSES}

This section provides the empirical results. First, we briefly discuss some descriptive statistics. Second, we present the regression results showing to what extent boards of directors' attributes can affect conditional accounting conservatism. Lastly, we provide a robustness check.

\subsection{Descriptive Statistics And Correlations}

Table 3 (Panel A, B) exposes descriptive statistics for the variables used in our model to investigate the relation between conditional accounting conservatism and board attributes. In this table, we report only descriptive statistics for returns and earnings for the four-year cumulative sample. We underline that the mean value of earnings before extraordinary items per share divided by the stock price is of $(0.185 \%)$, the minimum value is of $(-1.066 \%)$, and the maximum one is of $(2.085 \%)$. Return varies from $(-0.886 \%)$ to $(4.317 \%)$, and the mean value is $(0.103 \%)$. The mean value of board assiduity is $(89.2 \%)$. On average, the boards of directors of the companies of our sample consist of 12 members, with $50 \%$ of outside directors. The mean percentage of female representation on boards is $15.3 \%$. Panel B in Table 3 shows that in 53.7\% of the firm's sample, the CEO is also the chair of the board.

Table 3 (panel C) presents the Pearson correlation coefficient between the dependent variable (E/P), board attributes (MEET, ASSID, DUAL, BS, BI, GEND) and control variables (SIZE, LIT, LIST). Four board attributes are correlated with (E/P) which are MEET, BI, BS and DUAL. Most of the board attributes are significantly correlated with each other. The variance inflation factor (VIF) test indicates the absence of multicollinearity among the independent variables. Therefore, these variables can be included together in a regression model without estimation bias.

Table 3. Descriptive Statistics For Variables (Before Winsorizing)

\begin{tabular}{lccccc}
\hline Variables & Obs & Mean & Std. Dev. & Min & Max \\
\hline Panel A. Continuous variables & & & & & 2.085 \\
E/P & 374 & 0.185 & 0.267 & -1.066 & 4.317 \\
R & 374 & 0.103 & 0.719 & -0.886 & 23 \\
BS (before logarithmic & 374 & 12.056 & 3.589 & 3 & 1 \\
transformation) & 374 & 0.501 & 0.203 & 0 & 22 \\
BI & 374 & 8.203 & 2.672 & 3 & 1 \\
MEET (before logarithmic & 374 & 0.892 & 0.080 & 0.66 & 0.5 \\
transformation) & 374 & 0.153 & 0.105 & 0 & 160909,9 \\
ASSID & 374 & 18159.17 & 27887.79 & 10.04 & \\
GEND & & & & & \\
transformation) & & & & \\
\hline
\end{tabular}

Panel B. Dichotomous variables

\begin{tabular}{l|cc|cc}
\hline \multirow{2}{*}{ Variables } & \multicolumn{2}{|c|}{ Value 1 } & \multicolumn{2}{c}{ Value 0 } \\
\cline { 2 - 5 } D & Frequency & Proportion & Frequency & Proportion \\
\hline DUAL & 204 & 0.545 & 170 & 0.454 \\
\hline LIT & 201 & 0.537 & 173 & 0.462 \\
\hline LIST & 84 & 0.224 & 290 & 0.775 \\
\hline
\end{tabular}


(Table 3 continued)

\begin{tabular}{|c|c|c|c|c|c|c|c|c|c|c|}
\hline \multicolumn{11}{|c|}{ Panel C. The Pearson correlation } \\
\hline & $\mathbf{E} / \mathbf{P}$ & MEET & BI & BS & GEND & ASSID & DUAL & SIZE & LIST & VIF \\
\hline $\mathbf{E} / \mathbf{P}$ & 1 & & & & & & & & & \\
\hline MEET & $-0.10 * *$ & 1 & & & & & & & & 5.27 \\
\hline BI & $-0.10 * *$ & -0.05 & 1 & & & & & & & 1.41 \\
\hline BS & $0.16^{* *}$ & 0.01 & -0.00 & 1 & & & & & & 2.01 \\
\hline GEND & 0.07 & 0.03 & $0.10 * *$ & $0.10^{* *}$ & 1 & & & & & 2.36 \\
\hline ASSID & 0.035 & $-0.21 * * *$ & $0.27 * * *$ & $0.11^{* *}$ & 0.01 & 1 & & & & 3.79 \\
\hline DUAL & $-0.08 *$ & 0.05 & $-0.19 * * *$ & 0.04 & 0.01 & $-0.13 * * *$ & 1 & & & 1.19 \\
\hline SIZE & $0.14 * * *$ & $0.13 * * *$ & $0.11 * *$ & $0.58 * * *$ & $0.15^{* * *}$ & 0.00 & -0.05 & 1 & & 5.75 \\
\hline LIST & -0.0 & 0.05 & $0.29 * * *$ & $0.15^{* * *}$ & $0.16^{* * *}$ & $0.20 * * *$ & -0.00 & $0.30 * * *$ & 1 & 3.51 \\
\hline LIT & -0.04 & 0.07 & 0.05 & $-0.26 * * *$ & -0.08 & $-0.12 * *$ & -0.03 & $-0.21 * * *$ & $-0.14 * * * \quad 1$ & 1.31 \\
\hline
\end{tabular}

* Significant at the $10 \%$ level, ** Significant at the $5 \%$ level, *** Significant at the $1 \%$ level.

The above table shows Pearson correlations for the sample. E/P = is earnings before extraordinary items and discontinued operation per share deflated by the share price for the firm i cumulative from year $t-j$ to year $t$, with $\mathrm{j}$ varying from 0 to 3 ; $\mathrm{BS}=$ the natural logarithm of the total number of directors serving on the board; $\mathrm{BI}=$ the porportion of independent directors on board (the number of independent directors divided by board size); DUAL = an indicator variable coded 1 if the same person serves as both CEO and chairperson of the board, and 0 otherwise. MEET $=$ the natural logarithm of board meeting held per year; ASSID $=$ the percentage of board assiduity; GEND = the percentage of female directors on the board; SIZE = the natural logarithm of total sales; LIT = an indicator variable coded 1 if the company is classified as a high-ligation risk industry, and 0 otherwise. High-litigation industries are firms with SIC codes of 2833-2836, 3570-3577, 3600-3674,5200-5961, and 7370; LIST= a dummy variable, equal to 1 if the firm has an ADR traded in the U.S. that requires reconciliation to U.S. GAAP, and 0 otherwise.

\subsection{The Relation Between Board Attributes And Conditional Accounting Conservatism}

Table 4 reports the results of pooled regressions with backward cumulation (4 years). Model (1) presents the multivariate regression results based on asymmetric timeliness to measure conditional accounting conservatism. In models 2, 3 and 4, we allow the asymmetric timeliness coefficient to vary with board attributes and control variables. Because we generally find heteroscedasticity problems, we report corrected t-values for each coefficient

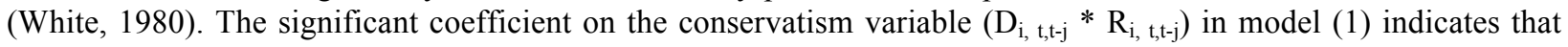
French companies use conservative financial reporting.

\subsubsection{Conditional Accounting Conservatism And Board Composition}

The coefficient on board $\operatorname{size}\left(B S_{i, t} * R_{i, t, t-j} * D_{i, t, t-j}\right)$ is significantly negative. This result provides empirical support for our first hypothesis (H1.a), which proposes that there is a negative relation between board size and conditional accounting conservatism. Our finding is consistent with previous studies such as Ahmed and Henry (2012), and contrary to the finding of Bushman et al. (2004) and Ahmed and Duellman (2007), who find no relation between board size and accounting conservatism. Several works on corporate governance show that when boards become too large, they are less effective monitors because they are hampered by coordination and communication difficulties as well as free-riding among board members (Jensen, 1993). Our finding supports the view that large boards are associated with less effective monitoring and decision-making (Eisenberg et al. 1998), which in turn gives managers greater discretion in the use of aggressive accounting practices.

Model (2) examines the relation between board independence and conditional accounting conservatism. The regression coefficient on board independence $\left(B I_{i, t} * R_{i, t, t-j} * D_{i, t, t-j}\right)$ is positive but insignificant. This result is not supportive of our second hypothesis, which posits that there is a positive relation between conditional accounting conservatism and board independence. Thus, independent directors may not be more inclined to monitor accounting quality. Empirical evidence by Bushman et al. (2004) and Ahmed and Henry (2012) support our finding, whereas Beekes et al. (2004) and Lim (2011) identified a significant relation between board independence and earnings timeliness. 
Table 4 presents the results of our third hypothesis, which proposes a negative relation between board leadership and conditional accounting conservatism. Examining the result for $\left(D U A L_{i, t} * R_{i, t, t-j} * D_{i, t, t-j}\right)$, this variable is not significant in our model. Our finding is similar to Ahmed and Duellman (2007) and contrary to previous studies conducted by Krishnan and Vivanathan (2008) and Lim (2011), who found a significant relation between board leadership and accounting conservatism.

\subsubsection{Conditional Accounting Conservatism And Gender Diversity}

Female participation on boards is predicted to be positively associated with the earnings timeliness coefficient. The coefficient on gender diversity $\left(G E N D_{i, t} * R_{i, t, t-j} * D_{i, t, t-j}\right)$ shows a significantly positive relation with the recognition of bad news relative to good news, measured by the reverse regression of returns and earnings. This result confirms our hypothesis H4. Our findings support prior research that finds that gender diversity affects firm performance. For instance, Srinidhi et al. (2011) find that boards with female participation exhibit higher earnings quality. In addition, Carter el al. (2003) and Campbell and Minguez-Vera (2008) document a positive association between female directors and firm performance. Accounting conservatism is an important aspect of good monitoring demanded by investors and a higher level of accounting conservatism therefore constitutes an important objective for the board. In our study, the board of directors can use female participation to achieve this objective. In this situation, managers have less incentive to choose aggressive accounting behaviour by preferring a higher level of accounting conservatism. This finding suggests that gender diversity in the boardroom delivers more prudent reporting practices and we therefore call for more female directors to be appointed on boards.

\subsubsection{Conditional Accounting Conservatism And Board Activities}

The coefficient on board meeting $\left(M E E T_{i, t} * R_{i, t, t-j} * D_{i, t, t-j}\right)$ shows a positive and significant association with conditional accounting conservatism. This result confirms our hypothesis H5.a, which presents a positive association between board meetings and conditional accounting conservatism. In conjunction with other studies such as Vafeas (1999), our result suggests that more active boards, as measured by the number of board meetings, require managers to practice better accounting choices. Adopting a higher degree of verification to recognize good news as gains than to recognize bad news as losses increases the level of reporting quality. The effect of board attendance on conditional accounting conservatism also appears to be significantly positive. The coefficient of the multivariate regression $\left(A S S I D_{i, t} * R_{i, t, t-j} * D_{i, t, t-j}\right)$ is positive and statistically significant. We argue that in the French context, board attendance improves board governance (see also Adams and Ferreira, 2009), which in turn is likely to improve the financial reporting quality and hence encourages managers to adopt a higher level of accounting conservatism. Overall, these results show that increased board activity appears to guarantee the quality of reporting.

Turning to control variables, the coefficient on firm size indicates a positive but insignificant relation with all board attributes. The coefficient on litigation is only positive and significant in models (3) and (4). Besides, we fail to find clear evidence that cross-listing firms exhibit greater conditional accounting conservatism, as measured by the reverse regression of returns and earnings. 
Table 4. Regression Results Of Effects Of Boards Of Directors' Attributes On Accounting Conservatism (Four-Year Cumulative Data)

\begin{tabular}{|c|c|c|c|c|c|}
\hline & & Model (1) & Model (2) & Model (3) & Model (4) \\
\hline & Expected Signs & $\begin{array}{c}\text { Coeff } \\
\text { (t-stat) }\end{array}$ & $\begin{array}{c}\text { Coeff } \\
\text { (t-stat) }\end{array}$ & $\begin{array}{c}\text { Coeff } \\
\text { (t-stat) }\end{array}$ & $\begin{array}{r}\begin{array}{c}\text { Coeff } \\
\text { (t-stat) }\end{array} \\
\end{array}$ \\
\hline Intercept & $?$ & $\begin{array}{l}0.232 * * * \\
(5.62)\end{array}$ & $\begin{array}{l}0.301^{* * *} \\
(4.90)\end{array}$ & $\begin{array}{l}0.32 * * * \\
(4.39) \\
\end{array}$ & $\begin{array}{l}0.313^{* * * *} \\
(5.48)\end{array}$ \\
\hline $\mathrm{R}$ & & $\begin{array}{l}0.147^{* * * *} \\
(4.45)\end{array}$ & $\begin{array}{l}0.174 * * * \\
(3.37)\end{array}$ & $\begin{array}{l}0.183^{* * *} \\
(5.51)\end{array}$ & $\begin{array}{l}0.189^{* * *} \\
(4.87)\end{array}$ \\
\hline $\mathrm{D}$ & & $\begin{array}{c}-0.026 \\
(-0.70) \\
\end{array}$ & $\begin{array}{r}-0.041 \\
(-0.78) \\
\end{array}$ & $\begin{array}{c}-0.099^{*} \\
(-1,69)\end{array}$ & $\begin{array}{r}-0.089 \\
(-1.59) \\
\end{array}$ \\
\hline $\mathrm{R} * \mathrm{D}$ & & $\begin{array}{l}0.256^{* * * *} \\
(2.85) \\
\end{array}$ & $\begin{array}{l}0.407 * * * \\
(2.71) \\
\end{array}$ & $\begin{array}{c}0.359^{* *} \\
(2.44) \\
\end{array}$ & $\begin{array}{l}0.343^{* *} \\
(2.34) \\
\end{array}$ \\
\hline BS & & & $\begin{array}{r}0.062 \\
(0.70) \\
\end{array}$ & & \\
\hline $\mathrm{BS} * \mathrm{R}$ & & & $\begin{array}{r}0.006 \\
(0.07)\end{array}$ & & \\
\hline $\mathrm{BS} * \mathrm{D}$ & & & $\begin{array}{c}-0.246 \\
(-1.54)\end{array}$ & & \\
\hline $\mathrm{BS} * \mathrm{R} * \mathrm{D}$ & $+/-$ & & $\begin{array}{c}-0.674^{*} \\
(-1.76) \\
\end{array}$ & & \\
\hline BI & & & $\begin{array}{l}-0.318^{* *} \\
(-2.28) \\
\end{array}$ & & \\
\hline $\mathrm{BI} * \mathrm{R}$ & & & $\begin{array}{l}0.556^{* * *} \\
(4.04)\end{array}$ & & \\
\hline $\mathrm{BI} * \mathrm{D}$ & & & $\begin{array}{l}0.452^{* *} \\
(2.14)\end{array}$ & & \\
\hline $\mathrm{BI} * \mathrm{R} * \mathrm{D}$ & + & & $\begin{array}{r}0.001 \\
(0.00) \\
\end{array}$ & & \\
\hline DUAL & & & $\begin{array}{l}-0.041 \\
(-1.47)\end{array}$ & & \\
\hline DUAL*R & & & $\begin{array}{r}0.009 \\
(0.14) \\
\end{array}$ & & \\
\hline DUAL*D & & & $\begin{array}{c}-0.069 \\
(-0.73)\end{array}$ & & \\
\hline DUAL*R*D & - & & $\begin{array}{r}-0.169 \\
(-1.01) \\
\end{array}$ & & \\
\hline MEET & & & & $\begin{array}{r}0.031 \\
(0.56) \\
\end{array}$ & \\
\hline MEET*R & & & & $\begin{array}{l}-0.149 * \\
(-1.75)\end{array}$ & \\
\hline MEET*D & & & & $\begin{array}{c}0.048 \\
(0.48) \\
\end{array}$ & \\
\hline $\mathrm{MEET}^{*} \mathrm{R} * \mathrm{D}$ & + & & & $\begin{array}{l}0.439^{* *} \\
(2.19)\end{array}$ & \\
\hline ASSID & & & & $\begin{array}{r}0.135 \\
(0.55)\end{array}$ & \\
\hline ASSID*R & & & & $\begin{array}{c}-0.364 \\
(-1.22) \\
\end{array}$ & \\
\hline ASSID*D & & & & $\begin{array}{r}0.645 \\
(0.93) \\
\end{array}$ & \\
\hline ASSID $* \mathrm{R} * \mathrm{D}$ & + & & & $\begin{array}{l}1.697 * * \\
(2.02)\end{array}$ & \\
\hline GEND & & & & & $\begin{array}{c}-0.048 \\
(-0.20)\end{array}$ \\
\hline GEND*R & & & & & $\begin{array}{c}-0.084 \\
(-0.31)\end{array}$ \\
\hline GEND*D & & & & & $\begin{array}{l}0.780 * * \\
(1.97)\end{array}$ \\
\hline
\end{tabular}


(Table 4 continued)

\begin{tabular}{|c|c|c|c|c|c|}
\hline & & Model (1) & Model (2) & Model (3) & Model (4) \\
\hline & Expected Signs & $\begin{array}{c}\text { Coeff } \\
\text { (t-stat) }\end{array}$ & $\begin{array}{c}\text { Coeff } \\
\text { (t-stat) }\end{array}$ & $\begin{array}{c}\text { Coeff } \\
\text { (t-stat) }\end{array}$ & $\begin{array}{c}\text { Coeff } \\
\text { (t-stat) }\end{array}$ \\
\hline GEND*R*D & + & & & & $\begin{array}{l}1.451^{* *} \\
(2.47)\end{array}$ \\
\hline SIZE & & & $\begin{array}{l}0.030^{* *} \\
(2.18)\end{array}$ & $\begin{array}{l}0.036^{* * * *} \\
(2.75)\end{array}$ & $\begin{array}{l}0.029 * * \\
(2.48) \\
\end{array}$ \\
\hline SIZE*R & & & $\begin{array}{r}0.014 \\
(0.50) \\
\end{array}$ & $\begin{array}{c}-0.002 \\
(-0.08) \\
\end{array}$ & $\begin{array}{c}-0.000 \\
(-0.03) \\
\end{array}$ \\
\hline SIZE*D & & & $\begin{array}{r}-0.015 \\
(-0.51)\end{array}$ & $\begin{array}{c}-0.034 \\
(-1.10)\end{array}$ & $\begin{array}{c}-0.045 \\
(-1.46)\end{array}$ \\
\hline SIZE*R*D & + & & $\begin{array}{c}0.043 \\
(1.34)\end{array}$ & $\begin{array}{r}0.015 \\
(0.67)\end{array}$ & $\begin{array}{c}0.011 \\
(0.56)\end{array}$ \\
\hline LIT & & & $\begin{array}{c}0.012 \\
(0.42)\end{array}$ & $\begin{array}{c}-0.023 \\
(-0.82)\end{array}$ & $\begin{array}{c}-0.030 \\
(-1.07)\end{array}$ \\
\hline $\mathrm{LIT}^{*} \mathrm{R}$ & & & $\begin{array}{c}0.073 \\
(0.92)\end{array}$ & $\begin{array}{r}0.001 \\
(0.02)\end{array}$ & $\begin{array}{c}0.015 \\
(0.26)\end{array}$ \\
\hline $\mathrm{LIT}^{*} \mathrm{D}$ & & & $\begin{array}{c}0.064 \\
(0.71) \\
\end{array}$ & $\begin{array}{c}0.11 \\
(1.10)\end{array}$ & $\begin{array}{r}0.099 \\
(1.00) \\
\end{array}$ \\
\hline $\mathrm{LIT}^{*} \mathrm{R} * \mathrm{D}$ & + & & $\begin{array}{r}0.061 \\
(0.28) \\
\end{array}$ & $\begin{array}{c}0.402 * \\
(1.89) \\
\end{array}$ & $\begin{array}{c}0.391 * \\
(1.84)\end{array}$ \\
\hline LIST & & & $\begin{array}{r}-0.076 \\
(-1.57) \\
\end{array}$ & $\begin{array}{l}-0.124 * * \\
(-2.06) \\
\end{array}$ & $\begin{array}{l}-0.110^{* *} \\
(-2.13)\end{array}$ \\
\hline $\mathrm{LIST}^{*} \mathrm{R}$ & & & $\begin{array}{c}0.06 \\
(0.88)\end{array}$ & $\begin{array}{c}0.147^{*} \\
(1.90)\end{array}$ & $\begin{array}{l}0.149 * * \\
(2.09)\end{array}$ \\
\hline $\mathrm{LIST}^{*} \mathrm{D}$ & & & $\begin{array}{c}0.069 \\
(-0.015)\end{array}$ & $\begin{array}{c}0.082 \\
(0.64)\end{array}$ & $\begin{array}{c}0.098 \\
(0.87)\end{array}$ \\
\hline $\mathrm{LIST}^{*} \mathrm{R} * \mathrm{D}$ & + & & $\begin{array}{c}-0.178 \\
(-1.14) \\
\end{array}$ & $\begin{array}{l}-0.361^{*} \\
(-1.88)\end{array}$ & $\begin{array}{c}-0.331^{*} \\
(-1.91)\end{array}$ \\
\hline $\mathrm{N}$ & & 374 & 374 & 374 & 374 \\
\hline Adjusted R ${ }^{2}$ & & 0.172 & 0.271 & 0.229 & 0.243 \\
\hline
\end{tabular}

* Significant at the $10 \%$ level, ** Significant at the $5 \%$ level, *** Significant at the $1 \%$ level.

The above table reports the results of the following two equations:

(Eq. 1): $\frac{E_{i, t, t-j}}{P_{i, t-j-1}}=\beta_{0+} \beta_{1} R_{i, t, t-j}+\beta_{2} D_{i, t, t-j}+\beta_{3} R_{i, t, t-j} * D_{i, t, t-j}+Y r+\epsilon_{t}$

(Eq.2): $\frac{E_{i, t, t-j}}{P_{i, t-j-1}}=\beta_{0+} \beta_{1} R_{i, t, t-j}+\beta_{2} D_{i, t, t-j}+\beta_{3} R_{i, t, t-j} * D_{i, t, t-j}+\beta_{4}$ Board attribute ${ }_{i, t}+\beta_{5}$ Board attribute ${ }_{i, t} * R_{i, t, t-j}+\beta_{6}$ Board attribute $_{i, t} * D_{i, t, t-j}+\beta_{7}$ Board attribute $_{i, t} * R_{i, t, t-j} * D_{i, t, t-j}+$ Other board attributes ${ }_{i, t} \&$ Control variables $_{i, t}+Y r+\epsilon_{t}$

$\mathrm{E}_{\mathrm{i}, \mathrm{t}, \mathrm{t}-j}$ is earnings before extraordinary items and discontinued operation per share for the firm i cumulative from year $t-j$ to year $t$, with $j$ varying from 0 to $3 ; P_{i, t-j-1}=$ the share price for the firm $i$ at the end of the year $t ; R_{i, t, t-j}=$ the buy-and-hold return for the firm i starting 4 months after the end of the fiscal year $t-j-1$ and ending 4 months after the end of the year $t ; D_{i, t, t-i}=$ an indicator variable set at 1 if $R_{i, t, t-i}$ is negative and 0 otherwise; Yr $=$ three dummy variables that control for the year of the test period. The first dummy variable takes the value of 1 for the year 2010 and 0 otherwise, the second takes the value of 1 for the year 2011 and 0 otherwise, and the last one takes the value of 1 for the year 2012 and 0 otherwise ; $\mathrm{BS}_{\mathrm{i}, \mathrm{t}}=$ the natural logarithm of the total number of directors serving on the board; $\mathrm{BI}$ i,t $=$ the porportion of independent directors on board (the number of independent directors divided by board size); DUAL $L_{i, t}=$ an indicator variable coded 1 if the same person serves as both CEO and chairperson of the board, and 0 otherwise; MEET $_{\mathrm{i}, \mathrm{t}}=$ the natural logarithm of board meeting held per year; ASSID $_{\mathrm{i}, \mathrm{t}}=$ the percentage of board assiduity; GEND ${ }_{i, t}=$ the percentage of female directors on the board; SIZE ${ }_{i, t}=$ the natural logarithm of total sales; LIT $_{\mathrm{i}, \mathrm{t}}=$ an indicator variable coded 1 if the company is classified as a high-ligation risk industry, and 0 otherwise. High-litigation industries are firms with SIC codes of 2833-2836, 3570-3577, 3600-3674,5200-5961, and 
7370; $\mathrm{LIST}_{\mathrm{i}, \mathrm{t}}=$ a dummy variable, equal to 1 if the firm has an ADR traded in the U.S. that requires reconciliation to U.S. GAAP, and 0 otherwise.

\subsection{Robustness Check}

To ensure the robustness of our empirical results, we use two alternative measures of accounting conservatism: the time-series model developed by Basu (1997) and the accrual-based measure by Givoly and Hayn (2000). The time-series model focuses on the extent to which earnings changes reverse. Reversal of earnings changes is an indication of the transitory component in earnings. Therefore, we expect negative earning's changes to reverse more than positive earnings changes in cases of conditional accounting conservatism (Lim, 2011). For this purpose, the following equation is estimated:

$\Delta E_{i, t} / P_{i, t-1}=\beta_{0}+\beta_{1} \Delta E_{i, t-1} / P_{i, t-2}+\beta_{2} D_{i, t-1}+\beta_{3} D_{i, t-1} * \Delta E_{i, t-1} / P_{i, t-2}+\mu_{i, t}$

Where:

$\beta_{0}$ is the intercept;

$\Delta E_{i, t} / P_{i, t-1}$ is the change in earnings per share for firm $\mathrm{i}$ in year $\mathrm{t}$ deflated by the share price;

$\Delta E_{i, t-1} / P_{i, t-2}$ is the change in earnings per share for firm i in year $\mathrm{t}-1$ deflated by the share price;

$D_{i, t-1}=1$ if $\Delta E_{i, t-1} / P_{i, t-2}$ is negative and 0 otherwise; and

$\mu$ is an error term.

The coefficient $\beta_{3}$ is expected to be negative if bad news is recognized timelier than good news.

To investigate the association between board attributes and conditional accounting conservatism, we include in the above regression all explanatory and control variables. For that, we use the following regression:

$\Delta E_{i, t} / P_{i, t-1}=\beta_{0}+\beta_{1} \Delta E_{i, t-1} / P_{i, t-2}+\beta_{2} D_{i, t-1}+\beta_{3} D_{i, t-1} * \Delta E_{i, t-1} / P_{i, t-2}+\beta_{4}$ Board attribute $_{i, t}+$ $\beta_{5}$ Board attribute $_{i, t} * \Delta E_{i, t-1} / P_{i, t-2}+\beta_{6}$ Board attribute $_{i, t} * D_{i, t-1}+\beta_{7}$ Board attribute $_{i, t} * \Delta E_{i, t-1} / P_{i, t-2} *$ $D_{i, t-1}+$ Other board attributes $s_{i, t} \&$ Control variables ${ }_{i, t}+\mathrm{Yr}+\mu_{i, t}$

All explanatory variables were interacted with $\Delta E / P, D$ and $D^{*} \Delta E / P$. We included three dummy variables in our regressions $(Y r)$ that control for fixed year effects. The coefficient $\beta_{7}$ is expected to be negative if board attribute variables increase conditional accounting conservatism in capturing economic income. Our second proxy of accounting conservatism is the accrual-based measure developed by Givoly and Hayn (2000), who argue that conservative accounting results in persistently negative accruals. To perform this measure, the following model was used:

$\operatorname{CONS}_{i, t}=\beta_{0}+\sum_{k} \beta_{k}$ Board attribute $_{k, i, t}+$ Control variables $_{i, t}+Y r+\epsilon_{i, t}$

$\operatorname{CONS}_{i, t}$ represents the income before extraordinary items less cash flows from operations plus depreciation expense deflated by total assets. To reduce the effect of temporary large accruals, which tend to reverse within a one or two years, our measure of accounting conservatism (CONS) is averaged over a three-year period centered on the year of interest, multiplied by negative one (Richardson et al., 2005). Positive value of CONS indicates greater accounting conservatism.

Tables 5 and 6 expose the results of the estimation of equations (3), (4) and (5) that asses the association between board attributes and accounting conservatism by using time-series and accrual measures. All our results confirm our above finding with Basu's measure. We find that both board activities and gender diversity increase accounting conservatism. As shown in tables 5 and 6 , we find that larger board size decreases accounting conservatism. Tables 5 and 6 also show that board independence and board leadership are not significantly associated with conditional accounting conservatism. 
Table 5. Regression Results Of Effects Of Boards Of Directors' Attributes On Accounting Conservatism (Time-Series Model)

\begin{tabular}{|c|c|c|c|c|c|}
\hline & & Model (5) & Model (6) & Model (7) & Model (8) \\
\hline & Expected signs & $\begin{array}{c}\text { Coeff } \\
\text { (t-stat) }\end{array}$ & $\begin{array}{c}\text { Coeff } \\
\text { (t-stat) }\end{array}$ & $\begin{array}{l}\text { Coeff } \\
\text { t-stat) }\end{array}$ & $\begin{array}{c}\text { Coeff } \\
\text { (t-stat) }\end{array}$ \\
\hline Intercept & $?$ & $\begin{array}{c}-0.003 \\
(-0.47) \\
\end{array}$ & $\begin{array}{l}-0.071^{* *} \\
(-2.44)\end{array}$ & $\begin{array}{l}-0.070^{* * *} \\
(-2.67)\end{array}$ & $\begin{array}{l}-0.067 * * \\
(-2.46)\end{array}$ \\
\hline$\Delta \mathrm{E} / \mathrm{P}$ & & $\begin{array}{l}-0.297 * * \\
(-2.37)\end{array}$ & $\begin{array}{l}-0.437^{*} \\
(-1.82) \\
\end{array}$ & $\begin{array}{c}-0.265^{*} \\
(-1.91) \\
\end{array}$ & $\begin{array}{l}-0.413^{* *} \\
(-2.54) \\
\end{array}$ \\
\hline $\mathrm{D}$ & & $\begin{array}{c}-0.007 \\
(-0.43) \\
\end{array}$ & $\begin{array}{r}0.015 \\
(0.39) \\
\end{array}$ & $\begin{array}{l}-0.028 \\
(0.72) \\
\end{array}$ & $\begin{array}{r}0.020 \\
(0.64) \\
\end{array}$ \\
\hline $\mathrm{D} * \Delta \mathrm{E} / \mathrm{P}$ & - & $\begin{array}{c}-0.438^{*} \\
(-1.66)\end{array}$ & $\begin{array}{r}-0.561 \\
(-1.32) \\
\end{array}$ & $\begin{array}{c}-0.361 \\
(-1.15) \\
\end{array}$ & $\begin{array}{l}-0.619^{*} \\
(-1.68)\end{array}$ \\
\hline BS & & & $\begin{array}{r}0.008 \\
(0.44) \\
\end{array}$ & & \\
\hline $\mathrm{BS} * \Delta \mathrm{E} / \mathrm{P}$ & & & $\begin{array}{c}-1.285 \\
(-1.25) \\
\end{array}$ & & \\
\hline $\mathrm{BS}^{*} \mathrm{D}$ & & & $\begin{array}{l}0.087^{*} \\
(1.86)\end{array}$ & & \\
\hline $\mathrm{BS}^{*} \mathrm{D} * \Delta \mathrm{E} / \mathrm{P}$ & $+/-$ & & $\begin{array}{l}3.288^{* *} \\
(2.29)\end{array}$ & & \\
\hline $\mathrm{BI}$ & & & $\begin{array}{c}-0.002 \\
(-0.06)\end{array}$ & & \\
\hline $\mathrm{BI}^{*} \Delta \mathrm{E} / \mathrm{P}$ & & & $\begin{array}{l}-0.461 \\
(0.54) \\
\end{array}$ & & \\
\hline $\mathrm{BI}^{*} \mathrm{D}$ & & & $\begin{array}{r}0.035 \\
(0.38)\end{array}$ & & \\
\hline $\mathrm{BI}^{*} \mathrm{D}^{*} \Delta \mathrm{E} / \mathrm{P}$ & - & & $\begin{array}{c}-0.560 \\
(-0.34) \\
\end{array}$ & & \\
\hline DUAL & & & $\begin{array}{r}0.003 \\
(0.30) \\
\end{array}$ & & \\
\hline $\mathrm{DUAL}^{*} \Delta \mathrm{E} / \mathrm{P}$ & & & $\begin{array}{r}0.343 \\
(1.29) \\
\end{array}$ & & \\
\hline DUAL $* D$ & & & $\begin{array}{c}-0.013 \\
(-0.44) \\
\end{array}$ & & \\
\hline $\mathrm{DUAL} * \mathrm{D} * \Delta \mathrm{E} / \mathrm{P}$ & + & & $\begin{array}{c}-0.53 \\
(-1.27) \\
\end{array}$ & & \\
\hline MEET & & & & $\begin{array}{r}0.005 \\
(0.33)\end{array}$ & \\
\hline $\mathrm{MEET}^{*} \Delta \mathrm{E} / \mathrm{P}$ & & & & $\begin{array}{c}-0.268 \\
(-0.94)\end{array}$ & \\
\hline MEET* D $^{*}$ & & & & $\begin{array}{c}-0.104^{*} \\
(-1.70) \\
\end{array}$ & \\
\hline $\mathrm{MEET}^{*} \mathrm{D} * \Delta \mathrm{E} / \mathrm{P}$ & - & & & $\begin{array}{c}-1.113^{*} \\
(-1.68)\end{array}$ & \\
\hline ASSID & & & & $\begin{array}{c}-0.022 \\
(-0.20) \\
\end{array}$ & \\
\hline $\mathrm{ASSID}^{*} \Delta \mathrm{E} / \mathrm{P}$ & & & & $\begin{array}{l}4.102 * * \\
(1.99) \\
\end{array}$ & \\
\hline ASSID*D & & & & $\begin{array}{r}0.081 \\
(0.29) \\
\end{array}$ & \\
\hline $\operatorname{ASSID} * \mathrm{D} * \Delta \mathrm{E} / \mathrm{P}$ & - & & & $\begin{array}{l}-1.537^{* *} \\
(-2.47)\end{array}$ & \\
\hline GEND & & & & & $\begin{array}{r}0.049 \\
(0.82)\end{array}$ \\
\hline $\mathrm{GEND}^{*} \Delta \mathrm{E} / \mathrm{P}$ & & & & & $\begin{array}{c}-1.201 \\
(-1.14)\end{array}$ \\
\hline GEND*D & & & & & $\begin{array}{c}-0.175 \\
(-1.50)\end{array}$ \\
\hline
\end{tabular}


(Table 5 continued)

\begin{tabular}{|c|c|c|c|c|c|}
\hline & & Model (5) & Model (6) & Model (7) & Model (8) \\
\hline & Expected signs & $\begin{array}{c}\text { Coeff } \\
\text { (t-stat) }\end{array}$ & $\begin{array}{c}\text { Coeff } \\
\text { (t-stat) }\end{array}$ & $\begin{array}{c}\text { Coeff } \\
\text { t-stat) }\end{array}$ & $\begin{array}{c}\text { Coeff } \\
\text { (t-stat) }\end{array}$ \\
\hline $\mathrm{GEND}^{*} \mathrm{D}^{*} \Delta \mathrm{E} / \mathrm{P}$ & - & & & & $\begin{array}{l}-1.501^{*} \\
(-1.74)\end{array}$ \\
\hline SIZE & & & $\begin{array}{l}-0.013^{* *} \\
(-2.21)\end{array}$ & $\begin{array}{l}-0.013 * * * \\
(-2.58)\end{array}$ & $\begin{array}{l}-0.014 * * * \\
(-2.82)\end{array}$ \\
\hline $\mathrm{SIZE}^{*} \Delta \mathrm{E} / \mathrm{P}$ & & & $\begin{array}{c}0.249^{*} \\
(1.70)\end{array}$ & $\begin{array}{c}0.128^{*} \\
(1.75) \\
\end{array}$ & $\begin{array}{c}0.117^{*} \\
(1.65)\end{array}$ \\
\hline SIZE* D & & & $\begin{array}{r}0.001 \\
(0.10) \\
\end{array}$ & $\begin{array}{l}0.021^{*} \\
(1.91)\end{array}$ & $\begin{array}{c}0.016 \\
(1.31) \\
\end{array}$ \\
\hline $\mathrm{SIZE}^{*} \mathrm{D}^{*} \Delta \mathrm{E} / \mathrm{P}$ & - & & $\begin{array}{l}-0.472 * * \\
(-2.07)\end{array}$ & $\begin{array}{r}0.052 \\
(0.27) \\
\end{array}$ & $\begin{array}{c}-0.068 \\
(-034) \\
\end{array}$ \\
\hline LIT & & & $\begin{array}{r}0.025 \\
(1.62) \\
\end{array}$ & $\begin{array}{l}0.040^{* *} \\
(2.49)\end{array}$ & $\begin{array}{c}0.024 \\
(1.57) \\
\end{array}$ \\
\hline $\mathrm{LIT}^{*} \Delta \mathrm{E} / \mathrm{P}$ & & & $\begin{array}{c}-0.232 \\
(-0.50)\end{array}$ & $\begin{array}{c}-0.311 \\
(-1.53) \\
\end{array}$ & $\begin{array}{c}0.038 \\
(0.19)\end{array}$ \\
\hline LIT* D $^{*}$ & & & $\begin{array}{l}0.047^{*} \\
(1.82)\end{array}$ & $\begin{array}{c}0.047^{*} \\
(1.73)\end{array}$ & $\begin{array}{c}0.052^{*} \\
(1.93)\end{array}$ \\
\hline $\mathrm{LIT}^{*} \mathrm{D}^{*} \Delta \mathrm{E} / \mathrm{P}$ & - & & $\begin{array}{r}0.843 \\
(1.22) \\
\end{array}$ & $\begin{array}{l}1.219^{*} \\
(1.86)\end{array}$ & $\begin{array}{c}0.698 \\
(1.21) \\
\end{array}$ \\
\hline LIST & & & $\begin{array}{c}0.036^{*} \\
(1.84) \\
\end{array}$ & $\begin{array}{c}0.036^{*} \\
(1.95) \\
\end{array}$ & $\begin{array}{c}0.032^{*} \\
(1.85)\end{array}$ \\
\hline $\mathrm{LIST}^{*} \Delta \mathrm{E} / \mathrm{P}$ & & & $\begin{array}{c}-0.330 \\
(-0.88) \\
\end{array}$ & $\begin{array}{c}-0.210 \\
(-0.74)\end{array}$ & $\begin{array}{c}-0.176 \\
(-0.70) \\
\end{array}$ \\
\hline LIST*D & & & $\begin{array}{r}-0.043 \\
(-1.05) \\
\end{array}$ & $\begin{array}{r}-0.071 \\
(-1.52) \\
\end{array}$ & $\begin{array}{c}-0.051 \\
(-1.31) \\
\end{array}$ \\
\hline $\mathrm{LIST}^{*} \mathrm{D}^{*} \Delta \mathrm{E} / \mathrm{P}$ & - & & $\begin{array}{c}0.904 * \\
(1.76) \\
\end{array}$ & $\begin{array}{r}0.141 \\
(0.26) \\
\end{array}$ & $\begin{array}{r}0.583 \\
(1.23) \\
\end{array}$ \\
\hline $\mathrm{N}$ & & 374 & 374 & 374 & 374 \\
\hline Adjusted $R^{2}$ & & 0.088 & 0.222 & 0.226 & 0.185 \\
\hline
\end{tabular}

* Significant at the $10 \%$ level, ** Significant at the $5 \%$ level, *** Significant at the $1 \%$ level

The above table reports the results of the following two equations:

(Eq. 3): $\Delta E_{i, t} / P_{i, t-1}=\beta_{0}+\beta_{1} \Delta E_{i, t-1} / P_{i, t-2}+\beta_{2} D_{i, t-1}+\beta_{3} D_{i, t-1} * \Delta E_{i, t-1} / P_{i, t-2}+\mu_{i, t}$

(Eq. 4): $\Delta E_{i, t} / P_{i, t-1}=\beta_{0}+\beta_{1} \Delta E_{i, t-1} / P_{i, t-2}+\beta_{2} D_{i, t-1}+\beta_{3} D_{i, t-1} * \Delta E_{i, t-1} / P_{i, t-2}+\beta_{4}$ Board attribute $_{i, t}+$ $\beta_{5}$ Board attribute $_{i, t} * \Delta E_{i, t-1} / P_{i, t-2}+\beta_{6}$ Board attribute $_{i, t} * D_{i, t-1}+\beta_{7}$ Board attribute $_{i, t} * \Delta E_{i, t-1} / P_{i, t-2} *$ $D_{i, t-1}+$ Other board attributes $s_{i, t} \&$ Control variables ${ }_{i, t}+\mathrm{Yr}+\mu_{i, t}$

$\Delta \mathrm{E}_{\mathrm{i}, \mathrm{t}} / \mathrm{P}_{\mathrm{i}, \mathrm{t}-1}=$ is the change in earnings per share for firm $\mathrm{i}$ in year $\mathrm{t}$ deflated by the share price; $\Delta \mathrm{E}_{\mathrm{i}, \mathrm{t}-1} / \mathrm{P}_{\mathrm{i}, \mathrm{t}-2}$ is the change in earnings per share for firm $i$ in year $t-1$ deflated by the share price; $D_{i, t-1}=1$ if $\Delta E_{i, t-1} / P_{i, t-2}$ is negative and 0 otherwise and $\mu$ is an error term. $\mathrm{Yr}=$ three dummy variables that control for the year of the test period. The first dummy variable takes the value of 1 for the year 2010 and 0 otherwise, the second takes the value of 1 for the year 2011 and 0 otherwise, and the last one takes the value of 1 for the year 2012 and 0 otherwise; $\mathrm{BS}{ }_{\mathrm{i}, \mathrm{t}}=$ the natural logarithm of the total number of directors serving on the board; $\mathrm{BI}_{\mathrm{i}, \mathrm{t}}=$ the porportion of independent directors on board (the number of independent directors divided by board size); $\mathrm{DUAL}_{\mathrm{i}, \mathrm{t}}=$ an indicator variable coded 1 if the same person serves as both CEO and chairperson of the board, and 0 otherwise; $\mathrm{MEET}_{\mathrm{i}, \mathrm{t}}=$ the natural logarithm of board meeting held per year; $\operatorname{ASSID}_{\mathrm{i}, \mathrm{t}}=$ the percentage of board assiduity; GEND ${ }_{\mathrm{i}, \mathrm{t}}=$ the percentage of female directors on the board; SIZE ${ }_{i, t}=$ the natural logarithm of total sales; $\operatorname{LIT}_{\mathrm{i}, \mathrm{t}}=$ an indicator variable coded 1 if the company is classified as a high-ligation risk industry, and 0 otherwise. High-litigation industries are firms with SIC codes of 2833-2836, 3570-3577, 3600-3674,5200-5961, and 7370; LIST $_{\mathrm{i}, \mathrm{t}}=$ a dummy variable, equal to 1 if the firm has an ADR traded in the U.S. that requires reconciliation to U.S. GAAP, and 0 otherwise. 
Table 6. Regression Results Of Effects Of Board Of Directors Attributes On Accounting Conservatism (Accruals Model)

\begin{tabular}{|c|c|c|c|c|}
\hline & & Model (9) & Model (10) & Model (11) \\
\hline & Expected signs & $\begin{array}{c}\text { Coeff } \\
\text { (t-stat) }\end{array}$ & $\begin{array}{c}\text { Coeff } \\
\text { (t-stat) }\end{array}$ & $\begin{array}{c}\text { Coeff } \\
\text { (t-stat) }\end{array}$ \\
\hline Intercept & $?$ & $\begin{array}{c}-1.068^{*} \\
(-1.89) \\
\end{array}$ & $\begin{array}{l}-3.253^{* *} \\
(-2.15)\end{array}$ & $\begin{array}{l}-1.422 * * \\
(-2.04)\end{array}$ \\
\hline BS & $+/-$ & $\begin{array}{c}0.156^{*} \\
(-1.77) \\
\end{array}$ & & \\
\hline BI & + & $\begin{array}{c}-0.194 \\
(-1.43) \\
\end{array}$ & & \\
\hline DUAL & - & $\begin{array}{c}-0.021 \\
(-0.42) \\
\end{array}$ & & \\
\hline MEET & + & & $\begin{array}{l}0.439^{* *} \\
(2.09)\end{array}$ & \\
\hline ASSID & + & & $\begin{array}{c}1.389^{*} \\
(1.82)\end{array}$ & \\
\hline GEND & + & & & $\begin{array}{c}0.697^{*} \\
(1.68) \\
\end{array}$ \\
\hline SIZE & + & $\begin{array}{l}0.172 * * \\
(2.05) \\
\end{array}$ & $\begin{array}{l}0.126^{* *} \\
(2.22)\end{array}$ & $\begin{array}{c}0.15^{* *} \\
(2.05) \\
\end{array}$ \\
\hline LIT & + & $\begin{array}{l}0.195^{* *} \\
(2.02) \\
\end{array}$ & $\begin{array}{l}0.179^{* * *} \\
(2.17) \\
\end{array}$ & $\begin{array}{l}0.217^{* *} \\
(2.04) \\
\end{array}$ \\
\hline LIST & + & $\begin{array}{c}0.26 \\
(0.84) \\
\end{array}$ & $\begin{array}{r}-0.035 \\
(-0.83) \\
\end{array}$ & $\begin{array}{c}-0.002 \\
(-0.07) \\
\end{array}$ \\
\hline $\mathbf{N}$ & & 374 & 374 & 374 \\
\hline Adjusted $\mathbf{R}^{2}$ & & 0.155 & 0.224 & 0.164 \\
\hline
\end{tabular}

* Significant at the $10 \%$ level, ** Significant at the $5 \%$ level, *** Significant at the $1 \%$ level

The above table reports the results of the following equation:

(Eq.5): CONS $_{i, t}=\beta_{0}+\sum_{k} \beta_{k}$ Board attribute $_{k, i, t}+$ Control variables $_{i, t}+Y r+\epsilon_{i, t}$

$\mathrm{CONS}_{\mathrm{i}, \mathrm{t}}$ is income before extraordinary items less cash flows from operations plus depreciation expense deflated by total assets. To reduce the effect of temporary large accruals, which tend to reverse within one or two years, our measure of accounting conservatism $\mathrm{CONS}_{\mathrm{i}, \mathrm{t}}$ is averaged over a three-year period centered on the year of interest, multiplied by negative 1 (Richardson et al., 2005). Positive values of $\mathrm{CONS}_{\mathrm{i}, \mathrm{t}}$ indicate greater accounting conservatism; $\mathrm{BS}_{\mathrm{i}, \mathrm{t}}=$ the natural logarithm of the total number of directors serving on the board; BI $\mathrm{i,t}=\mathrm{the}$ porportion of independent directors on board (the number of independent directors divided by board size); DUAL $\mathrm{i}_{\mathrm{i}, \mathrm{t}}$ $=$ an indicator variable coded 1 if the same person serves as both CEO and chairperson of the board, and 0 otherwise; MEET $_{\mathrm{i}, \mathrm{t}}=$ the natural logarithm of board meeting held per year; $\mathrm{ASSID}_{\mathrm{i}, \mathrm{t}}=$ the percentage of board assiduity; GEND ${ }_{i, t}=$ the percentage of female directors on the board; SIZE ${ }_{i, t}=$ the natural logarithm of total sales; $\mathrm{LIT}_{\mathrm{i}, \mathrm{t}}=$ an indicator variable coded 1 if the company is classified as a high-ligation risk industry, and 0 otherwise. High-litigation industries are firms with SIC codes of 2833-2836, 3570-3577, 3600-3674,5200-5961, and 7370; LIST $_{i, t}=$ a dummy variable, equal to 1 if the firm has an ADR traded in the U.S. that requires reconciliation to U.S. GAAP, and 0 otherwise.

\section{CONCLUSION}

The main purpose of this paper is to examine the relation between board attributes and conditional accounting conservatism among SBF120 companies during 2009-2012. Six board attributes are investigated, namely: board size; board independence; board leadership, gender diversity; board meeting frequency; and board attendance. Overall, our results show that board meeting frequency and attendance are positively associated with accounting conservatism. Board activities improve board governance, which in turn are likely to improve the financial reporting quality in the French context. Second, board size negatively affects conditional accounting conservatism. Large boards are associated with less effective monitoring, confused decision-making, and less membership coordination (Eisenberg et al., 1998), which can reduce the quality of accounting information. In 
addition, we find a positive association between gender diversity and conditional accounting conservatism. This positive influence suggests that female directorship improves board monitoring, which in turn is likely to require a higher degree of verification for recognizing good news than bad news in financial statements. Lastly, in contrast to what is expected, board leadership and independence do not appear to have a significant relation with conditional accounting conservatism. We checked the robustness of our empirical results by using alternative measures of accounting conservatism.

\section{AUTHOR INFORMATION}

Nabila BOUSSAID is a Ph.D student in Finance in co-tutelle program at HEC Management School - University of Liège and Institut Supérieur de Gestion (ISG)-University of Sousse. Her current research field is focused on corporate governance and accounting conservatism. Nabila holds a master degree in Finance and International Trade from ISG-University of Sousse, magna cum laude. E-mail: Nabila.Boussaid@doct.ulg.ac.be; (corresponding author)

Taher HAMZA is an Associate Professor of Finance at IHEC-Carthage, University of Carthage. He chaired the doctoral committee at University of Sousse (2012-2014). He is also Research Fellow at VALLOREM - University of Orléans, France) and LAMIDED - University of Sousse. He holds a M. Phil from University of Jean Moulin (I.A.E.- Lyon III, France) in 1987, a Ph.D. in Finance from University of Grenoble II (Grenoble, France) in 1993 and a HDR degree (Habilitation for Supervising Doctoral Research) in 2009 from University of Sousse. Before joining the Tunisia State University, Professor Hamza has taught for more than 10 years in France at both Ecole Supérieure de Commerce of Clermont Ferrand and IAE Lyon III. His main research interests are corporate finance, corporate governance, and mergers and acquisitions. He published many academic papers in top French and international refereed journals. E-mail: taher.hamza@topnet.tn

Danielle SOUGNE is Full Professor of finance at HEC Management School - University of Liège. She holds a master degree in finance and a $\mathrm{PhD}$ in applied economics from the Catholic University of Louvain. She is also holder of the KBL chair in Fund Industry. Prof. Sougné carries out research on fund management and administration in an international context. Her current research focuses on liquidity risk and performance measures of funds. She is also an active teacher in the bank sector and handles a wide range of financial courses, ranking from fundamentals to advanced levels of specialization for finance professionals. She is member of the board and of the audit committee of KBC Ancora. E-mail: danielle.sougne@ulg.ac.be

\section{REFERENCES}

Adams, R. B., \& Ferreira, D. (2009). Women in the boardroom and their impact on governance and performance. Journal of Financial Economics, 94(2), 291-309.

Ahmed, A. S., \& Duellman, S. (2007). Evidence on the role of accounting conservatism in corporate governance. Journal of Accounting and Economics, 43(2-3), 411-437.

Ahmed, K., \& Henry, D. (2012). Accounting conservatism and voluntary corporate governance mechanisms by Australian firms. Accounting and Finance, 52(3), 631-662.

Aiken, L. S., \& West, S. G. (1991). Multiple regression: Testing and interpreting interactions. Sage.

Ambrose, M. L., \& Schminke, M. (1999). Sex differences in business ethics: The importance of perceptions. Journal of Managerial Issues, 454-474.

Ball, R. (2001). Infrastructure requirements for an economically efficient system of public financial reporting and disclosure. Brookings-Wharton papers on financial services, 2001(1), 127-169.

Ball, R., \& Shivakumar, L. (2005). Earnings quality in UK private firms: comparative loss recognition timeliness. Journal of Accounting and Economics, 39(1), 83-128.

Basu, S. (1997). The conservatism principle and the asymmetric timeliness of earnings. Journal of Accounting and Economics, 24(1), 3-37.

Beasley, M. S. (1996). An empirical analysis of the relation between the board of director composition and financial statement fraud. Accounting Review, 443-465.

Beaver, W. H., \& Ryan, S. G. (2005). Conditional and unconditional conservatism: Concepts and modeling. Review of Accounting Studies, 10(2-3), 269-309. 
Beekes, W., Pope, P., \& Young, S. (2004). The link between earnings timeliness, earnings conservatism and board composition: evidence from the UK. Corporate Governance: An International Review, 12(1), 47-59.

Bliss, J. H. (1924). Management through accounts. Ronald Press Company.

Bushman, R., Chen, Q., Engel, E., \& Smith, A. (2004). Financial accounting information, organizational complexity and corporate governance systems. Journal of Accounting and Economics, 37(2), 167-201.

Campbell, K., \& Mínguez-Vera, A. (2008). Gender diversity in the boardroom and firm financial performance. Journal of Business Ethics, 83(3), 435-451.

Carter, D. A., Simkins, B. J., \& Simpson, W. G. (2003). Corporate governance, board diversity, and firm value. Financial Review, 38(1), 33-53.

Chen, Q., Hemmer, T., \& Zhang, Y. (2007). On the relation between conservatism in accounting standards and incentives for earnings management. Journal of Accounting Research, 45(3), 541-565.

Chi, W., Liu, C., \& Wang, T. (2009). What affects accounting conservatism: A corporate governance perspective. Journal of Contemporary Accounting and Economics, 5(1), 47-59.

Cohen, J. R., \& Pant, L. W. (1998). The effect of gender and academic discipline diversity on the ethical evaluations, ethical... Accounting Horizons, 12(3), 250-270.

Conger, J. A., Finegold, D., \& Lawler, E. E. (1998). Appraising boardroom performance. Harvard Business Review, 76, 136-164.

Cronbach, L. J. (1987). Statistical tests for moderator variables: Flaws in analyses recently proposed.

Davidson, R., Goodwin-Stewart, J., \& Kent, P. (2005). Internal governance structures and earnings management. Accounting and Finance, 45(2), 241-267.

Dechow, P. M., Sloan, R. G., \& Sweeney, A. P. (1995). Detecting earnings management. Accounting Review, 193225.

Dechow, P. M., Sloan, R. G., \& Sweeney, A. P. (1996). Causes and consequences of earnings manipulation: An analysis of firms subject to enforcement actions by the sec. Contemporary Accounting Research, 13(1), 136.

Eisenberg, T., Sundgren, S., \& Wells, M. T. (1998). Larger board size and decreasing firm value in small firms. Journal of Financial Economics, 48(1), 35-54.

Fama, E. F., \& Jensen, M. C. (1983). Separation of ownership and control. Journal of Law and Economics, $301-325$.

Feltham, G. A., \& Ohlson, J. A. (1995). Valuation and clean surplus accounting for operating and financial activities. Contemporary Accounting Research, 11(2), 689-731.

Forbes, D. P., \& Milliken, F. J. (1999). Cognition and corporate governance: Understanding boards of directors as strategic decision-making groups. Academy of Management Review, 24(3), 489-505.

Garcia, J. M. G., Osma, B. G., \& Penalva, F. (2009). Accounting conservatism and corporate governance. Review of Accounting Studies, 14(1), 161-201.

García Lara, J. M., Osma, B. G., \& Penalva, F. (2007). Board of directors' characteristics and conditional accounting conservatism: Spanish evidence. European Accounting Review, 16(4), 727-755.

Givoly, D., \& Hayn, C. (2000). The changing time-series properties of earnings, cash flows and accruals: Has financial reporting become more conservative?. Journal of Accounting and Economics, 29(3), 287-320.

Hermalin, B. E., \& Weisbach, M. S. (2003). Boards of directors as an endogenously determined institution: A survey of the economic literature. Economic Policy Review 9, 7-21.

Hillman, A. J., Shropshire, C., \& Cannella, A. A. (2007). Organizational predictors of women on corporate boards. Academy of Management Journal, 50(4), 941-952.

Jelinek, M., \& Adler, N. J. (1988). Women: World-class managers for global competition. The Academy of Management Executive, 2(1), 11-19.

Jensen, M. C., \& Meckling, W. H. (1979). Theory of the firm: Managerial behavior, agency costs, and ownership structure (pp. 163-231). Springer Netherlands.

Jensen, M. C. (1993). The modern industrial revolution, exit, and the failure of internal control systems. The Journal of Finance, 48(3), 831-880.

Klein, A. (2002). Audit committee, board of director characteristics, and earnings management. Journal of Accounting and Economics, 33(3), 375-400.

Krishnan, G. V., \& Visvanathan, G. (2008). Does the SOX Definition of an Accounting Expert Matter? The Association between Audit Committee Directors' Accounting Expertise and Accounting Conservatism. Contemporary Accounting Research, 25(3), 827-858. 
Krishnan, G. V., \& Parsons, L. M. (2008). Getting to the bottom line: An exploration of gender and earnings quality. Journal of Business Ethics, 78(1-2), 65-76.

Kwon, Y. K., Newman, D. P., \& Suh, Y. S. (2001). The demand for accounting conservatism for management control. Review of Accounting Studies, 6(1), 29-52.

LaFond, R., \& Watts, R. L. (2008). The information role of conservatism. The Accounting Review, 83(2), 447-478.

Lang, M., Smith Raedy, J., \& Wilson, W. (2006). Earnings management and cross listing: Are reconciled earnings comparable to US earnings?. Journal of Accounting and Economics, 42(1), 255-283.

Lara, J. M. G., \& Mora, A. (2004). Balance sheet versus earnings conservatism in Europe. European Accounting Review, 13(2), 261-292.

Lim, R. (2011). Are corporate governance attributes associated with accounting conservatism?. Accounting and Finance, 51(4), 1007-1030.

Lipton, M., \& Lorsch, J. W. (1992). A modest proposal for improved corporate governance. The Business Lawyer, 59-77.

Qiang, X. (2007). The effects of contracting, litigation, regulation, and tax costs on conditional and unconditional conservatism: cross-sectional evidence at the firm level. The Accounting Review, 82(3), 759-796.

Rahman, R. A., \& Haniffa, R. M. (2005). The effect of role duality on corporate performance in Malaysia. Corporate Ownership and Control, 2(2), 40-47.

Riley Jr, W. B., \& Chow, K. V. (1992). Asset allocation and individual risk aversion. Financial Analysts Journal, 32-37.

Roychowdhury, S., \& Watts, R. L. (2007). Asymmetric timeliness of earnings, market-to-book and conservatism in financial reporting. Journal of Accounting and Economics, 44(1), 2-31.

Ryan, S. G. (2006). Identifying conditional conservatism. European Accounting Review, 15(4), 511-525.

Shrader, C. B., Blackburn, V. B., \& Iles, P. (1997). Women in management and firm financial performance: An exploratory study. Journal of Managerial Issues, 355-372.

Srinidhi, B., Gul, F. A., \& Tsui, J. (2011). Female Directors and Earnings Quality. Contemporary Accounting Research, 28(5), 1610-1644.

Vafeas, N. (1999). Board meeting frequency and firm performance. Journal of Financial Economics, 53(1), 113142 .

Watts, R. L., \& Zimmerman, J. L. (1978). Towards a positive theory of the determination of accounting standards. Accounting Review, 112-134.

Watts, R. L., \& Zuo, L. (2012). Accounting conservatism and firm value: evidence from the global financial crisis. Working Paper

Watts, R. L. (2003). Conservatism in accounting part I: Explanations and implications. Accounting Horizons, 17(3), 207-221.

Weisbach, M. S. (1988). Outside directors and CEO turnover. Journal of Financial Economics, 20, $431-460$.

Williamson, O. E. (1983). Organization form, residual claimants, and corporate control. Journal of Law and Economics, 351-366.

Xie, B., Davidson III, W. N., \& DaDalt, P. J. (2003). Earnings management and corporate governance: the role of the board and the audit committee. Journal of Corporate Finance, 9(3), 295-316.

Yermack, D. (1996). Higher market valuation of companies with a small board of directors. Journal of Financial Economics, 40(2), 185-211. 


\section{NOTES}

